\title{
TECHNO-ECONOMIC ANALYSIS: PRELIMINARY ASSESSMENT OF PYROLYSIS OIL PRODUCTION COSTS AND MATERIAL ENERGY BALANCE ASSOCIATED WITH A TRANSPORTABLE FAST PYROLYSIS SYSTEM
}

\author{
Phil Badger, ${ }^{\text {a }}$ Scott Badger, ${ }^{\mathrm{a}}$ Maureen Puettmann, ${ }^{\mathrm{b}, *}$ Philip Steele, ${ }^{\mathrm{c}}$ and Jerome Cooper ${ }^{\mathrm{c}}$ \\ A techno-economic analysis was performed for a 100 dry-ton/day \\ $(90,719 \mathrm{~kg} /$ day) fast pyrolysis transportable plant. Renewable Oil \\ International $\circledast$ LLC provided the life cycle cost of operating a 100 dry- \\ ton/day fast pyrolysis system using southern pine wood chips as \\ feedstock. Since data was not available from an actual large-scale plant, \\ the study examined data obtained from an actual 15 dry-ton/day pilot \\ plant and from several smaller plants. These data were used to obtain \\ base figures to aid in the development of models to generate scaled-up \\ costs for a larger 100 dry-ton/day facility. Bio-oil represented $60 \%$ of \\ mass of product yield. The cost for the bio-oil from fast pyrolysis was \\ valued at \$0.94/gal. Energy cost bio-oil and char was valued at \\ $\$ 6.35 / M M B T U$. Costs associated with purchasing feedstocks can \\ drastically influence the final cost of the bio-oil. The assumed cost of \\ feedstocks was $\$ 25 /$ wet ton or $\$ 50 /$ dry ton. This paper is part of a larger \\ study investigating the economic and environmental impacts for \\ producing bio-oil / biocide wood preservatives.
}

Keywords: Pyrolysis; Bio-oil; Wood chips; Economic analysis

Contact information: a: President \& Chief Manager, Renewable Oil International ${ }^{\circledR} L L C, 3115$ Northington Court, P.O. Box 26, Florence, AL 35630 USA; b: LCA Consultant, WoodLife, 8200 NW Chaparral Drive, Corvallis, Oregon, USA; c: Professor, d:Research Associate, Department of Forest Products, Mississippi State University, P.O. Box 9820, Mississippi State, MS 39762 USA;* maureen.puettmann@q.com

\section{INTRODUCTION}

With growing concerns about our use of fossil-based fuels and associated greenhouse gas emissions, utilization of biomass for alternative fuel sources is on the rise. Biomass is defined as organic matter that is renewable and bio-degradable. Woody biomass, which is comprised primarily of carbohydrates and lignin, is produced through the natural process of photosynthesis. In nature woody biomass accumulates below and above ground in roots, stumps, bark, leaves, small stems, and branches of dead and live small trees and shrubs. One of the major sources of woody biomass is from logging residues. Wood processing mills are another source of biomass where these can be burned onsite for energy generation (Puettmann and Wilson 2005) or higher valued residues can be made into panel products and used in such products as structural paneling or furniture. Until recently it was assumed that biomass collection and conversion to bio-fuels was too expensive. With increasing fossil fuel prices together with rapid 
technological advances in conversion processes, the interest in bio-fuels is growing. Biomass availability was assessed by Gan and Smith (2006) on a regional basis. They reported that nearly half of the national available biomass (17.5 million dry tons) is located in the southern United States, and this material has the potential to displace 8.4 million tons of carbon.

Biomass can be converted to either ethanol or bio-oil. Ethanol is an alcohol fuel made from the sugars found in plants and produced by fermentation or an enzymatic reaction. Bio-oil is defined as an organic liquid fuel produced by a process called pyrolysis. Fast pyrolysis is the chemical decomposition organic materials by heat $\left(500^{\circ} \mathrm{C}\right)$ in the absence of oxygen (Bridgwater et al. 1999). After cooling and condensation, a dark brown mobile liquid (bio-oil) is formed. Bio-oil typically has a heating value about half that of conventional fuel oil. The conversion process produces three main products: a liquid organic, char, and gases. While the procedure is related to the traditional pyrolysis processes for making charcoal, fast pyrolysis is an advanced process that is carefully controlled to give high yields of liquid. Several studies have reported yields of $50-75 \%$ bio-oil, 15-25\% char, and 10-20\% gas (Gregoire and Bain 1994; Mullaney and Farag 2002).

For nearly a decade techno-economic analyses have been performed for pyrolysis oil production (Gregoire and Bain 1994; Mullaney and Farag 2002; Ringer et al. 2006). Costs to produce bio-oil can be significantly different depending on the analysis and size of plant. Large-scale plant systems tend to generate lower production costs, despite the fact that they have not yet achieved commercial status. A study by researchers at the University of New Hampshire investigated the conversion of wood chips to bio-oil as a substitute for \#2 fuel oil (Mullaney and Farag 2002). They looked at a DynaMotive fast pyrolysis reactor with feedstock rates of 100, 200, and 400 metric tons/day. Production cost ranged from $\$ 17 / \mathrm{GJ}$ for a 100 -dry metric ton/day (110 ton/day) to $\$ 13 / \mathrm{GJ}$ for a larger plant with a feed input of 200-dry metric ton/day (Mullaney and Farag 2002). Other reports have estimated production costs at $\$ 11.7 / \mathrm{GJ}$ and $\$ 14.5 / \mathrm{GJ}$ for a 220-dry ton/day and 110-dry ton/day plant size, respectively (Ringer et al. 2006).

This study provides a techno-economic analysis for the development of a transportable 100 dry-ton/day (dtpd) fast pyrolysis module system able to process pine wood chips (Renewable Oil International ${ }^{\circledR}$ (ROI) 2009). The largest plant ROI has fabricated to date is a 15-dtpd. Since data was not available from an actual large-scale plant project, this study utilized data obtained from an ROI pilot plant and from several smaller plants with a similar design. The data was used to obtain base figures as a model to generate scaled-up costs for a larger 100-dtpd facility.

Mobile systems are defined as trailer-mounted units, typically smaller than 50dtpd. Larger units are manufactured in modular configurations that are transportable (not necessarily wheel-mounted). The 100-dtpd system would incorporate two or more modules that can be hooked together once on site. The modular units can remain at one site for its entire useful life or be transported to a new area based on feedstock availability. If the available feedstock dries up or feedstock prices become too expensive, the modular units can be picked up by crane and transported to a new location. The enclosed modules also provide protection from the elements and security when a plant is placed outdoors. 


\section{EXPERIMENTAL}

\section{Process Description}

Feedstock preparation

Feedstocks determine the type of pre-processing equipment required for particle size reduction and the amount of drying required. For this study it was assumed that whole tree pine wood chips with an average moisture content of 50\% (wet basis) (100\% oven-dry basis) were processed. The whole tree chips (0.06-0.12 inch; 2-3 mm) were dried on an onsite dryer from a moisture content of 50\% to a maximum moisture content of 10\% (wet basis). For this analysis a feedstock ash content of 1\% (by weight) was assumed. In the case that wood chips did not meet the criteria, they would require additional pre-processing. Depending on feedstocks, pre-processing equipment includes a chipper, grinder, dryer, or a hammermill. Pre-processing equipment assumed for this study included a dryer and a hammermill.

\section{Pyrolysis reactor}

For true fast pyrolysis the feedstock is rapidly heated to bring the feedstock particles to temperatures of 752 to $1,022^{\circ} \mathrm{F}$ (400 to $550{ }^{\circ} \mathrm{C}$ ) within roughly one second. The thin particle dimension facilitates rapid heat transfer and improves pyrolysis oil yield and quality. While in the absence of oxygen, the organic materials in the feedstock are converted to a complex mixture of oxygenated hydrocarbons. Three separate products are produced during pyrolysis: a condensable liquid (pyrolysis oil), a charcoal coproduct, and a non-condensable gas (syngas). Pyrolysis oil is the target product of the fast pyrolysis process with an approximate density of $10 \mathrm{lbs} / \mathrm{gal}$ at $59^{\circ} \mathrm{F}(1.20 \mathrm{~kg} / \mathrm{L} 15$ ${ }^{\circ} \mathrm{C}$ ) with an Low Heat Value (LHV) energy content of approximately 80,000 Btu/gal (13$18 \mathrm{MJ} / \mathrm{kg})$. Summary tables for mass and energy balances for the 100-dtpd (90,718 $\mathrm{kg} /$ day) module are included in Tables 1 and 2.

Table 1. Summary of Mass Balance for $100-d t p d(90,718 \mathrm{~kg} /$ day) Input Feed for Transportable Module

\begin{tabular}{|c|c|c|c|}
\hline Material, wet basis & $\begin{array}{c}\text { Input green Ib/hr } \\
\text { (kg/hr) }\end{array}$ & $\begin{array}{c}\text { Output lb/hr } \\
\text { (kg/hr) }\end{array}$ & $\begin{array}{c}\text { Percent Yield based } \\
\text { on output }\end{array}$ \\
\hline Wood chips, 50\% MC & $\begin{array}{c}16,666 \\
(7,560)\end{array}$ & $\begin{array}{c}7,407 \\
(3,360)\end{array}$ & $46.8 \%$ \\
\hline Water vapor from dryer & & $\begin{array}{c}5,000 \\
(2,268)\end{array}$ & $31.6 \%$ \\
\hline Bio-oil & & $\begin{array}{c}2,083 \\
(946)\end{array}$ & $13.2 \%$ \\
\hline Char & & $\begin{array}{c}92 \\
(42)\end{array}$ & $0.6 \%$ \\
\hline Ash & & $\begin{array}{c}1,250 \\
(567)\end{array}$ & $7.9 \%$ \\
\hline Syngas & & $\begin{array}{c}15,832 \\
(7,183)\end{array}$ & $100 \%$ \\
\hline Totals & $\begin{array}{c}925 \\
(420)\end{array}$ & \\
\hline Difference & 16,666 & &
\end{tabular}


Table 2. Summary of Energy Balance for 100-dtpd (90,718 kg/day) Input Feed for Transportable Module

\begin{tabular}{|c|c|c|}
\hline+2 & $\begin{array}{c}\text { Input BTU/hr } \\
\text { (MJ/hr) }\end{array}$ & $\begin{array}{l}\text { Output BTU/hr } \\
\text { (MJ/hr) }\end{array}$ \\
\hline Wood chips, $50 \% \mathrm{MC}$, wet basis & $\begin{array}{c}74,997,000 \\
(79,126) \\
\end{array}$ & \\
\hline \multicolumn{3}{|l|}{ Water vapor from dryer } \\
\hline Bio-oil & & $\begin{array}{c}40,000,000 \\
(42,202)\end{array}$ \\
\hline Char & & $\begin{array}{c}24,996,000 \\
(26,372)\end{array}$ \\
\hline Furnace ash & & $\begin{array}{c}13,708 \\
(14)\end{array}$ \\
\hline Syngas & & $\begin{array}{c}5,625,000 \\
(5,935)\end{array}$ \\
\hline System heat losses & & $\begin{array}{c}4,362,292 \\
(4,602)\end{array}$ \\
\hline Totals & & $\begin{array}{c}74,997,000 \\
(79,126)\end{array}$ \\
\hline
\end{tabular}

The primary factors that influence the pyrolysis oil yield are the type of feedstock and the cleanliness of the feedstock processed (ash content) (Table 3).

Table 3. Percent Yield of Products from Fast Pyrolysis for 100-dt (dry ton)/day (90,718 kg/day) Transportable Module

\begin{tabular}{|c|c|c|c|}
\hline Material, wet basis & $\begin{array}{c}\text { Input lb/hr } \\
\text { (kg/hr) }\end{array}$ & $\begin{array}{c}\text { Output lb/hr } \\
\mathbf{( k g / h r )}\end{array}$ & Percent Yield \\
\hline Wood Chips, 10\% & $\begin{array}{c}9,260 \\
(4,200)\end{array}$ & & \\
MC, (green basis) & & $\begin{array}{c}835 \\
(379)\end{array}$ & \\
\hline Water vapor & & $\begin{array}{c}5,000 \\
(2,268)\end{array}$ & $60 \%$ \\
\hline Bio-oil & & $\begin{array}{c}2,083 \\
(907)\end{array}$ & $24 \%$ \\
\hline Char & & $\begin{array}{c}92 \\
(42)\end{array}$ & $1 \%$ \\
\hline Ash & & $\begin{array}{c}1,250 \\
(567)\end{array}$ & $15 \%$ \\
\hline Syngas & & $\begin{array}{c}9,260 \\
(4,200)\end{array}$ & $100 \%$ \\
\hline Totals & & & \\
\hline
\end{tabular}


Debarking pine logs before chipping will help eliminate much of the dirt, stone and other debris that can accumulate during the logging process. Since these impurities are inorganic in nature, their presence will increase the ash content and lower the pyrolysis oil yield. The ROI module produced yields of $60,24,15$, and $1 \%$ for bio-oil, char, gas, and ash, respectively. Yields as high as $75 \%$ for bio-oil were reported by Innovative Natural Resources Solutions LLC (2004), while bio-oil yields between 60 and 70\% from fast pyrolysis are more typically reported (Ringer et al. 2006; Putsche 2004; Mullaney and Farag 2002). All of the syngas produced is burned on-site for process heat. The char is also used for process heat or sold for revenue.

Elemental analysis was not performed on the bio-oil product for this study. The assumption was that the elemental and physical properties of the pyrolysis products would fall within the range of published data (Gregoire and Bain 1995; Ringer et al. 2006; Innovative Natural Resource Solutions 2004; Farag and Mullaney 2002). Some typical properties of wood-derived bio-oil are: moisture content 15-30\%, pH 2.5-3.7, carbon content 48-60\%, hydrogen content 5.9-7.2\%, oxygen content 34-45\%, and ash content 0.01-0.2\% (Bridgwater et al. 1999).

\section{Furnace}

The syngas produced (15\% by wt.) by the process is piped to a furnace associated with the plant and burned for process heat (Table 4). The use of syngas for process heat would offset the use of fossil-based energy for process heat. Seventy-five percent $(1,562$ $\mathrm{lb} / \mathrm{hr}$ ) of the char produced is used for process heat for the plant. The remaining twentyfive percent (521 lb/hr) is sold for revenue. Over 23 million BTUs (MMBTU) per hour $(24,893 \mathrm{MJ} / \mathrm{hr})$ were produced in the furnace. The dryer consumed over $7 \mathrm{MMBTU} / \mathrm{hr}$ or $30 \%$ and the pyrolysis reactor consumed over 16 MMBTU or $69 \%$ of total energy. A small amount of light petroleum gas is necessary at start-up of the system. This amount was assumed to be insignificant compared to the total energy generated and consumed by the system. Figure 1 contains the flow diagram of the ROI Transportable Module System. The solid lines represent mass flow through each process and the gray shaded lines represent energy flows.

Table 4. Furnace Inputs and Energy Requirements from Fast Pyrolysis for 100dt/day $(90,718 \mathrm{~kg} /$ day) Transportable Module

\begin{tabular}{|c|c|c|}
\hline \multirow{2}{*}{$\begin{array}{c}\text { Product } \text { I } \\
\text { Process }\end{array}$} & $\begin{array}{c}\text { Self-generated Energy input } \\
\text { BTU/hr } \\
\text { (MJ/hr) }\end{array}$ & $\begin{array}{c}\text { Energy Requirements } \\
\text { BTU/hr } \\
\text { (MJ/hr) }\end{array}$ \\
\hline Char & $18,000,000$ & \\
\hline Syngas & $(18,991)$ & \\
\hline Dryer & $5,594,185$ & $7,407,407$ \\
& $(5,902)$ & $(7,815)$ \\
\hline Pyrolysis and & & $16,186,778$ \\
system loss & & $(17,078)$ \\
\hline Totals & $23,594,185$ & $23,594,185$ \\
& $(24,893)$ & $(24,893)$ \\
\hline
\end{tabular}




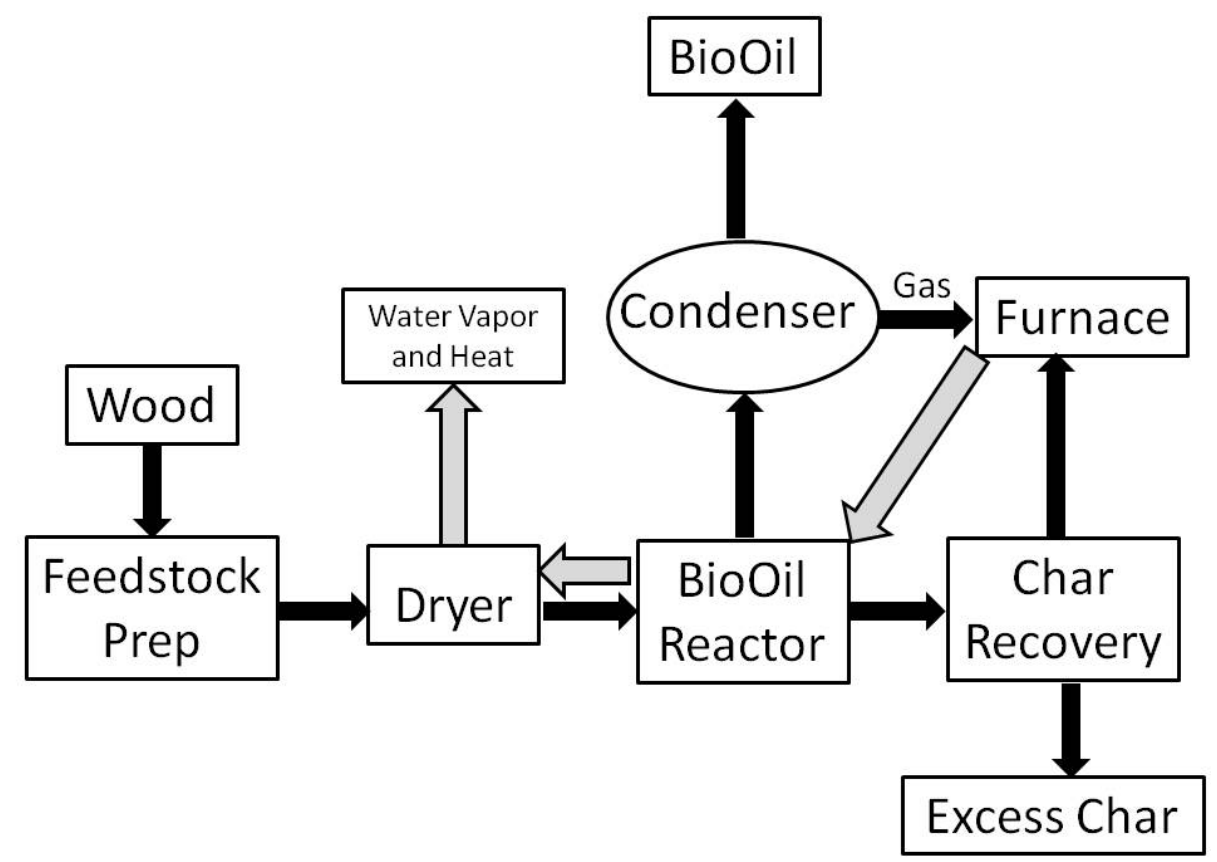

Fig. 1. ROI system diagram for production of bio-oil from pine wood chips

\section{RESULTS AND DISCUSSION}

\section{Economic Analysis}

Equipment requirements and capital cost estimations are based on the assumptions of feedstock inputs and product yields described earlier. Total capital cost associated with a 100-dtpd (200 wet-ton/day) ROI fast pyrolysis transportable module was $\$ 6,030,816$. Equipment included in capital cost are: the plant modules, a dryer, a hammer mill, and a feedstock metering bin, along with all associated conveyors and, site preparation and permits. Capital costs do not follow a linear relationship with the plant size and, in fact, there is a strong decreasing economy of scale with decreasing plant sizes.

\section{Variable Costs}

Operating costs include all variable and fixed costs associated with the 100-dtpd ROI transportable system minus any capital depreciation or interest payments. Variable costs are expenses that vary with the level of production. Variable costs included feedstock costs, electrical and thermal requirements, maintenance, and other miscellaneous expenses. The price of feedstocks within the feedstock procurement area can greatly influence the system's cash flows. For this very reason, transportable plants allow the system to be moved away from areas where resources may have become scarce or expensive. However, for this analysis, we assumed the plant is affixed to one location. Feedstock for this study, a $\$ 25.00 /$ green ton ( $\$ 50.00 /$ dry ton) for pine wood chips with a moisture content of $50 \%$ was used. Feedstock expenses are summarized in Table 5. 
Comparative feedstock prices are summarized in Table 6. Feedstock can range from $\$ 30$ - \$50 per dry ton. Difference in cost can be attributed to wood species, bark content, transportation distances, market conditions, and other factors. Thus, fluctuations in feedstock cost can drastically influence cash flows. Costs in this study were based on an assumed $80 \%$ online plant operating efficiency which is considered conservative and should rapidly increase to over $90 \%$ as the technology matures. Total pyrolysis oil yield was $60 \%$ at a feedstock cost of $\$ 1,460,000$ per year (Table 5). An operation year consisted of 292 working days $(=80 \%$ online). The plant yields are not dependent on feedstock moisture, since all feedstocks are dried to a maximum moisture content of $10 \%$ before entering the process reactor. The moisture in the feedstock will vaporize and recondense as a component of the bio- oil. Moisture content does, however, affect the overall system energy requirements and the volume of feedstock that has to be purchased and pre-processed.

Table 5. Based on 100-dtpd Feedstock Input

\begin{tabular}{|l|l|r|l|l|}
\hline \multicolumn{1}{|c|}{ Feedstock } & \multicolumn{1}{c|}{ Units } & \multicolumn{1}{c|}{ Per Day } & \multicolumn{1}{c|}{ Per Ton } & \multicolumn{1}{c|}{ Per Yr } \\
\hline & & & & \\
\hline Feedstock, plant size (wet tons) & Ton & $100(200)$ & & \\
\hline $\begin{array}{l}\text { Feedstock processed } \\
80 \% \text { online/day }\end{array}$ & Ton & 160 & & \\
\hline Pyrolysis oil liquid & Gal & 12,000 & & $3,504,000$ \\
\hline Feedstock, pine wood chips & \$ & 5,000 & $\begin{array}{l}\$ 50(\$ 25 \text { green } \\
\text { ton })\end{array}$ & $\$ 1,460,000$ \\
\hline
\end{tabular}

Table 6. Feedstock Cost Analysis Comparison

\begin{tabular}{|c|c|c|c|}
\hline Plant Size & Feed Cost \$ Dry Ton & Species & Source \\
\hline $100 \mathrm{dtpd}$ & $\$ 40(\$ 20$ green ton $)$ & pine & Ringer et al. 2006 \\
\hline $550 \mathrm{dtpd}$ & $\$ 30(\$ 15$ green ton $)$ & pine & Putsch 2004 \\
\hline $440 \mathrm{dtpd}$ & $\$ 33(\$ 18$ green ton $)$ & Pine/spruce & Mullaney 2002 \\
\hline $1000 \mathrm{dtpd}$ & $\$ 40$ dry ton & & Gregorie and Bain 1994 \\
\hline
\end{tabular}

Figure 2 illustrates what effects fluctuations in feedstock price can have on the internal rate of return (IRR) and the net present value (NPV). The IRR is the rate of return that investors would earn if they invested in this project, rather than investing their money somewhere else. The NPV is defined as the total present value of a time series of cash flows. The IRR of an investment is the interest rate at which the net present value of costs (negative cash flows) of the investment equal the net present value of the benefits (positive cash flows) of the investment. If there are no capital constraints, all projects with a positive net present value should be accepted. Two other variables that can influence IRR swings are the payroll costs and the market value of the products and coproducts. A financial pro forma based on the above assumptions--(\$25.00/green ton and $80 \%$ online operating time) --returned an IRR of $35 \%$ and an NPV of $\$ 1,969,614$. Revenue streams were calculated by pricing the pyrolysis oil at a $15 \%$ discount to the fossil fuel it is competing against. In this scenario, residual heating oil was selected. The 
discount provides potential customers an incentive to switch to pyrolysis oil, and to compensate for any end-use device modifications, if required. The Energy Information Agency's (EIA 2010) ${ }^{1}$ national average price for residual heating oil for 2008 was $\$ 13.17 / \mathrm{MMBtu}$ (\$1.976/gallon). Therefore, pyrolysis oil was valued at $\$ 10.99 / \mathrm{MMBtu}$ (\$1.65/gallon), and a conservative \$75.00/ton was assumed for char revenue streams. By increasing the online operating time to $90 \%$ the system would return a $39 \%$ IRR with an NPV of $\$ 2,462,329$.

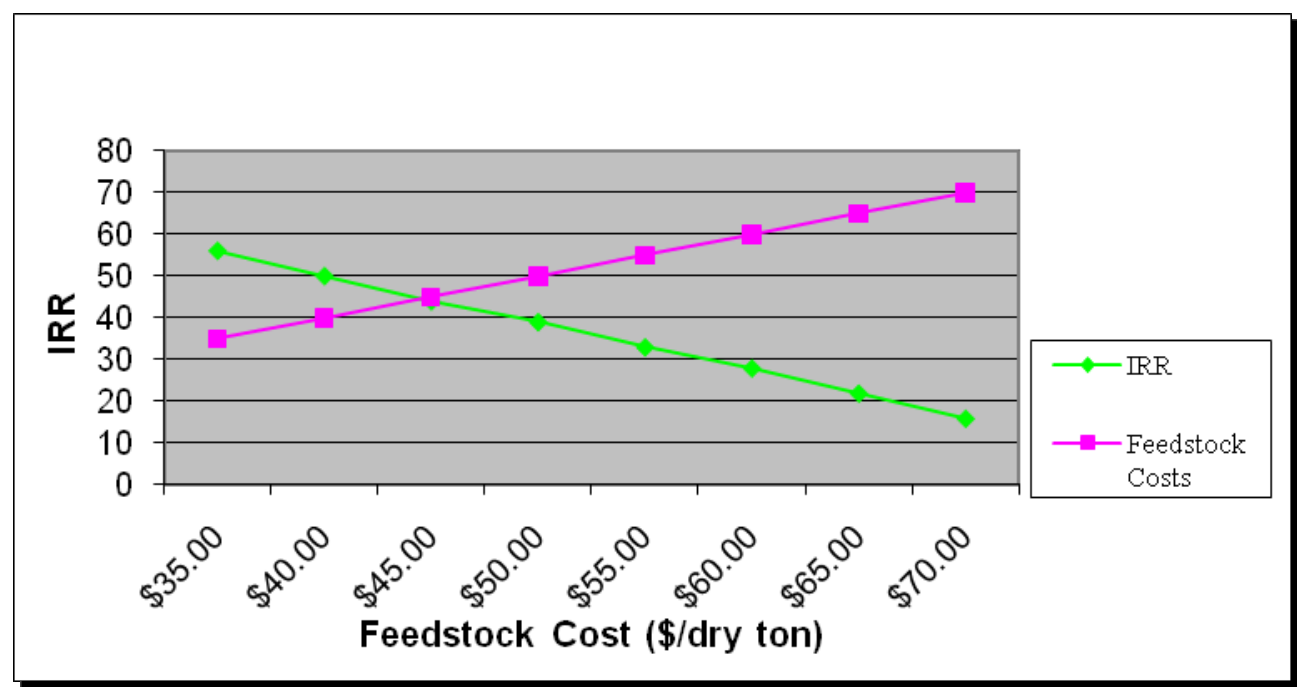

Figure 2. Feedstock cost influence on the Internal Rate of Return (IRR), from Fast Pyrolysis for $100-\mathrm{dt} / \mathrm{day}(90,718 \mathrm{~kg} / \mathrm{day})$ Transportable Module, $90 \%$ online

The feedstock moisture content determines the amount of energy required for drying. Thermal process energy for the reactor and dryer can be provided from the syngas and supplemented by the char produced by the process. With $50 \%$ feedstock moisture content, all of the syngas generated and $75 \%$ of the char generated provide the thermal energy requirements for both the dryer and pyrolysis reactor.

The use of the syngas and char can offset the need for fossil based energy sources. Therefore, the only revenue stream lost is from the opportunity cost of selling char to competing markets. In some cases, char has more value in outside markets instead of using it onsite to provide process heat. In those cases, the added revenue from the sale of char would cover the additional costs of fossil fuels needed to meet the thermal requirements. Thermal energy requirements for drying pine wood chips and the amount of char co-product needed to produce the energy (thermal drying energy) are listed in Table 4. The remaining syngas not required for the pyrolysis oil reactor would also be available for drying.

As long as co-products are used to provide process heat for the dryer and the reactor, the thermal energy costs impacting operating costs will be minimal. The remaining variable costs include electrical utilities, product transportation expenses, maintenance, and miscellaneous expenses (Table 7).

\footnotetext{
${ }^{1}$ http://tonto.eia.doe.gov/dnav/pet/hist/LeafHandler.ashx?n=PET\&s=D300600002\&f=M
} 
Table 7. Annual Cost for Energy Associated with Operations, Transportation, and Maintenance for a 100-dry ton/day Plant Size using Pine Wood Chips Feedstock

\begin{tabular}{|c|c|}
\hline & Cost/year \\
\hline Energy cost & \\
\hline Grid electricity & $\$ 104,869$ \\
\hline Thermal energy & 0 \\
\hline Transportation cost & \\
\hline Pyrolysis oil & $\$ 76,692$ \\
\hline Maintenance cost & \\
\hline Parts, labor, supplies & $\$ 91,551$ \\
\hline Total & $\$ \mathbf{2 7 3 , 1 1 2}$ \\
\hline
\end{tabular}

The electrical requirements for the ROI system are based on horsepower totals and other known electrical components. Thermal energy costs will fluctuate based on the amount of moisture content in the feedstock, pre-processing equipment required, and the amount of co-products substituted for fossil fuels. Of course many costs will also fluctuate based on geographic area. A flex fuel burner is included as part of the furnace module in the initial capital cost. This burner allows the operator to use both syngas and char from the process as well as propane or industrial natural gas. A 100-dtpd (80\% online) system, processing pine wood chips, will produce 7,008 tons $(6,350,293 \mathrm{~kg})$ of char (24\% yield) per year (Table 3) or the equivalent of $18 \mathrm{MMBTU} / \mathrm{yr}(18,991 \mathrm{MJ} / \mathrm{yr})$ (Table 4). This energy is available for process heat or an additional revenue stream. For this scenario (pine wood chips @ 50\% mc), all of the syngas and 75\% of the char produced cover all of the thermal energy requirements for both the reactor and dryer.

The pyrolysis oil transportation costs were estimated on a cost-per-gallon basis. The average haul distance was assumed to be 40 miles $(64 \mathrm{~km})$ one way to market. No transportation costs were included for the remaining $25 \%$ of char available for resale. The maintenance expenses are for high temperature grease, gasket material, couplings, component replacement, and other standard maintenance, most of which will occur on an annual basis. The maintenance costs were estimated at $2.5 \%$ of the pyrolysis module cost (not the total system cost). The low maintenance expenses are a direct result of the simplicity of ROI's technology. The simple design as well as the use of readily available components allows plant operators to perform maintenance instead of requiring a specialized craftsman.

\section{Fixed costs}

The fixed costs associated with ROI systems include employee wages, fringe benefits, insurance, laboratory fees, loan payments, and overhead costs. Plant operator scheduling was based on the fuel ethanol industry, since the plant will operate $24 x 7$ with two 12-hour operator shifts-similar to the schedules worked in the fuel ethanol industry. An operation year consisted of 292 working days. Within the fuel ethanol industry, operators work two days, and then are off two days, then on three days, then off three 
days, and the cycle is repeated. Many fuel ethanol plants have the night and day (12 hour) shifts trade places every month. All other employees will normally work from $8 \mathrm{am}-5 \mathrm{pm}$ Monday through Friday. Salaries from the fuel ethanol industry were used as a guide ${ }^{2}$.

Each day shift will have two operators-one to watch the control console and two to float around the plant and to handle keeping the feed hopper full, receipt of feedstock, and product load outs. The operator positions are cross-trained and interchangeable and will rotate in their jobs every day. Two operators per shift can operate the plant. Four to five truck loads equate to 100 tons of feedstock per day and feedstock deliveries and product load-outs will only be conducted during the day when a third operator is available.

Thus, 10 operators are needed. The third operator will handle also routine maintenance and assist both of the primary operators as needed and fill in if one of the primary operators needs to be off for any reason. If the plant should go down, all operators on duty are available to work on the plant. Due to the simplicity of the ROI technology, an engineering degree is not required for plant operators, although an aptitude for mechanical and/or electrical systems is required. ROI's goal is to offer a completely automated system. As ROI's system automation progresses, fewer employees should be required, thereby decreasing operating costs.

Salary and benefit estimates are provided in Table 8 based on information gathered from the ethanol industry ${ }^{1}$. The travel costs are primarily for an assistant manager handling outside marketing and feedstock procurements. Salaries and benefits will vary by geographic regions.

Table 8. ROI System 100-dtpd Annual Wage \& Labor Breakdown

\begin{tabular}{|l|cc|}
\hline Labor & & \\
\hline Plant manager & $\$$ & 55,000 \\
\hline Asst plant manager/bookkeeper & $\$$ & 35,000 \\
\hline $\begin{array}{l}\text { Plant operators (Console, Floating) (10 @ } \\
\$ 30,000 / y r)\end{array}$ & $\$$ & 300,000 \\
\hline Subtotal labor w/o fringe & $\$$ & 390,000 \\
\hline Labor fringe rate (40\%) & $\$$ & 156,000 \\
\hline Subtotal labor w/ fringe & $\$$ & 546,000 \\
\hline & \multicolumn{2}{|c|}{} \\
\hline Travel related costs & \multicolumn{2}{|c|}{} \\
\hline Automobile lease, fuel, insurance & $\$$ & 7,200 \\
\hline Travel & $\$$ & 12,000 \\
\hline Subtotal travel & $\$$ & 19,200 \\
\hline
\end{tabular}

An estimation factor of $1 \%$ of gross receipts for liability insurance was applied. Property insurance varies by geographic area and depends on many variables such as the percent assessed to find the tax valuation basis and the local and state property tax millage rates. Property and liability insurance rates can be found in Table 9 along with other general and administrative expenses.

\footnotetext{
${ }^{2}$ M. Bryan, BBI International LLC, Cotopaxi, CO, personal communication
} 
Table 9. Average Annual General \& Administrative Fixed Expenses

\begin{tabular}{|l|c|}
\hline & 100-dtpd \\
\hline Property insurance & $\$ 42,113$ \\
\hline Liability insurance & $\$ 39,539$ \\
\hline Laboratory analysis & $\$ 19,150$ \\
\hline Miscellaneous & $\$ 6,277$ \\
\hline
\end{tabular}

A summary of all operating and capital costs discussed previously for the100-dtpd ROI fast pyrolysis system described in this paper is found in Table 10.

Table 10. ROI Operating \& Capital Costs Breakdown (US \$/yr), 80\% Online

\begin{tabular}{|c|c|c|}
\hline & Unit per yr & 100-dtpd \\
\hline & & Pine Wood Chips \\
\hline Variable Costs & & \$ (US dollars) \\
\hline Feedstock costs (\$25.00/green ton) & $\$$ & $1,460,000$ \\
\hline Electrical utilities & $\$$ & 104,869 \\
\hline Thermal utilities & $\$$ & 0 \\
\hline Maintenance & $\$$ & 91,551 \\
\hline Trucking costs (pyrolysis oil) & $\$$ & 76,692 \\
\hline Subtotal Variable Costs & $\$$ & $1,733,112$ \\
\hline \multicolumn{3}{|l|}{ Fixed costs } \\
\hline Wages \& benefits \& travel & $\$$ & 565,200 \\
\hline Property insurance & $\$$ & 42,113 \\
\hline Liability insurance & $\$$ & 39,539 \\
\hline Laboratory fees & $\$$ & 19,150 \\
\hline Subtotal Fixed Costs & $\$$ & 666,002 \\
\hline $\begin{array}{l}\text { TOTAL Annual Operating Costs (fixed + } \\
\text { variable) }\end{array}$ & $\$$ & $2,399,114$ \\
\hline ROI system capital costs ${ }^{1 /}$ & $\$$ & $6,030,816$ \\
\hline $\begin{array}{l}\text { Annual loan payment } 100 \% \text { borrowed } \\
\text { (9\% interest rate, } 10 \text { year term) }\end{array}$ & $\$$ & 916,749 \\
\hline Annual gallons produced ( $80 \%$ online), $60 \%$ yield & $\mathrm{gal} / \mathrm{yr}$ & $3,504,000$ \\
\hline $\begin{array}{c}\text { Total Annual Operating Costs with Loan } \\
\text { Payments }\end{array}$ & $\$ / y r$ & $3,315,863$ \\
\hline TOTAL ( $80 \%$ online) & \$/gal & 0.94 \\
\hline
\end{tabular}

${ }^{1 /}$ Equipment included in capital cost are the plant modules, a dryer, a hammer mill, and a feedstock metering bin, along with all associated conveyors and, site preparation and permits.

The relatively low cost of production using the fast pyrolysis process described in this study and the multiple products produced allows bio-oils to compete in today's fossil fuel market. As shown below in Table 11, a 100-dtpd system processing wood chips at $\$ 25.00 /$ green ton can recover all operating cost and capital loan payments by selling its 
products and co-products for $\$ 6.35 / \mathrm{MMBtu}$, assuming $80,000 \mathrm{Btu} / \mathrm{gal}$ for pyrolysis oil and $12,000 \mathrm{Btu} / \mathrm{lb}$ for char. That same company, if paying more than $\$ 6.35 / \mathrm{MMBtu}$ for their fossil fuel will save revenue by using pyrolysis oil and the co-products onsite.

Table 11. Breakeven Analysis using both Pyrolysis Oil and Char Production Energy Content, $90 \%$ online.

\begin{tabular}{|l|c|c|}
\hline & Unit & $\begin{array}{c}\text { 100-dtpd } \\
\text { Wood Chips }\end{array}$ \\
\hline Operating cost (90\% online) & $\$ / y r$ & $2,341,238$ \\
\hline Operating cost + loan payment & $\$ / y r$ & $3,257,987$ \\
\hline Energy content for pyrolysis oil produced/yr, 90\% online & $\begin{array}{l}\mathrm{MMBtu} / \mathrm{yr} \\
(1000 \mathrm{MJ} / \mathrm{yr})\end{array}$ & $\begin{array}{c}315,360 \\
(322,722)\end{array}$ \\
\hline Energy content for char produced/yr, 90\% online & $\mathrm{MMBtu} / \mathrm{yr}$ & 197,100 \\
$(1000 \mathrm{MJ} / \mathrm{yr})$ & $(207,952)$ \\
\hline Subtotal energy content & $\mathrm{MMBtu} / \mathrm{yr}$ & 512,460 \\
$(1000 \mathrm{MJ} / \mathrm{yr})$ & $(530,674)$ \\
\hline $\begin{array}{l}\text { Breakeven sales costs to offset operating cost + loan } \\
\text { payments }\end{array}$ & $\begin{array}{c}\$ / \mathrm{MMBTU} \\
(1000 \mathrm{MJ} / \mathrm{yr})\end{array}$ & $\begin{array}{c}6.35 \\
(6.14)\end{array}$ \\
\hline
\end{tabular}

Table 12 below lists the products and co-products associated with the $100 \mathrm{dtpd}$ fast pyrolysis system described in this study and their energy-equivalent values. The lower half of the table equates the energy content provided by the pyrolysis oil and char to industrial natural gas, propane and No.2 fuel oil. Pyrolysis oil is considered a substitution for all of these fossil fuels. For example, Table 12 shows that by using the 315,360 BTU/yr (Table 11) of energy provided by the pyrolysis oil, a company could offset their use of 227,697 gallons of No.2 fuel oil. This is a huge energy savings, especially if the company is processing waste products generated onsite.

Table 12. Bio-oil Product and Co-product Outputs Processing Wood Chips and Fossil Fuel Equivalents (90\% Online)

\begin{tabular}{|c|c|c|c|c|c|c|c|}
\hline & & \multicolumn{2}{|c|}{$\begin{array}{l}\text { Pyrolysis Oil } \\
\text { Production }\end{array}$} & \multicolumn{2}{|c|}{ Char Production } & \multicolumn{2}{|c|}{ Syngas Production } \\
\hline & & gal/yr & MMBTU/yr & tons/yr & MMBTU/yr & gal/yr & MMBTU/yr \\
\hline & & $3,942,000$ & 315,360 & 8,213 & 197,100 & $147,836,667$ & 44,348 \\
\hline & Unit & \multicolumn{6}{|c|}{ Fuel Substitution Offsets per year } \\
\hline Natural gas & $\mathrm{ft} 3$ & \multicolumn{2}{|c|}{$340,929,730$} & \multicolumn{2}{|c|}{$213,081,081$} & \multicolumn{2}{|c|}{$47,943,784$} \\
\hline No.2 Fuel oil & gal & \multicolumn{2}{|c|}{227,697} & \multicolumn{2}{|c|}{142,310} & \multicolumn{2}{|c|}{32,020} \\
\hline Propane & gal & \multicolumn{2}{|c|}{$1,553,859$} & \multicolumn{2}{|c|}{$2,142,391$} & \multicolumn{2}{|c|}{44,348} \\
\hline
\end{tabular}

The Energy Information Administration (EIA)(2010) provided industrial sector fuel prices from 2004-2009: Natural Gas \$7.81/1000 $\mathrm{ft}^{3}$ (\$8.44/MMBTU), No.2 Fuel Oil $\$ 2.12 / \mathrm{Gal}$ (\$15.30/MMBtu), and Propane \$1.68/gal (\$18.26/MMBtu). When compared to the breakeven analysis above (\$6.35/MMBTU ROI System) the cost benefits of the 
ROI system are obvious. Pyrolysis oil with its co-products can compete in today's industrial fossil fuel market without the help of government subsidies. Additional cost benefits such as off-setting waste disposal are not included. Carbon, renewable energy, and tax credits, as well as any other government subsidies are not included in this study. The addition of any of the above would have a very positive impact on the profitability of an ROI system.

\section{CONCLUSIONS}

1. The ROI $100 \mathrm{dtpd}$ fast pyrolysis transportable plant, pyrolysis oil cost is $\$ 0.94 /$ gal

2. Capitol cast were determined to be $\$ 6,030,816$, with total annual operating cost of $\$ 3,315,863$ per year.

3. Bio-oil represented $60 \%$ by mass of product yield. Char and Syngas yields were $24 \%$ and $15 \%$, respectively.

4. Feedstock quality has the greatest influence on energy requirements and cost of final product.

5. The primary factors that influence the pyrolysis oil yield are the type of feedstock and the cleanliness of the feedstock processes (ash content).

6. Feedstock annual cost is $\$ 1,460,000$ assuming at purchase price of $\$ 25$ per green ton.

7. Pyrolysis oil production with its co-products can compete in today's industrial fossil fuel market without the help of government subsidies.

8. The cost of bio-oil and char per MMBTU is $\$ 6.35$, while the cost of \#2 fuel oil, natural gas, and propane are \$15.30, \$7.81, and \$18.26 MMBTU, respectively.

9. A 100-drpd transportable system as described in this study can recover all operating and loan payments by selling its products and co-products for \$6.35/MMBtu

\section{ACKNOWLEDGMENTS}

This study was funded by the USDA/DOE Biomass Research and Development Program. The authors are grateful for the funding.

\section{REFERENCES CITED}

Bridgwater, A., Czernik, S. Diebold, J., Meier, D., Oasmaa, A., Peacocke, C., Piskorz, J., and Radlein, D. (1999). Fast Pyrolysis of Biomass: A Handbook. CPL Press. CPL Scientific Publishing Group, UK. 188 pp.

Energy Information Administration (EIA) . 2010. http://www.eia.doe.gov/.

Gan, J., and Smith, C. T. (2006). "Availability of logging residues and potential for electricity production and carbon displacement in the USA,” Biomass and Bioenergy 30, 1011-1020.

Gregoire, C. E., and Bain, R. L. (1994). “Technoeconomic analysis of the production of biocrude from wood,” Biomass and Energy 7(1-6), 275-283. 
Innovative Natural Resources Solutions LLC. (2004). http://www.inrsllc.com/.

Mullaney, H. and Farage, I. H. (2002). “Technical, environmental and economic feasibility of bio-oil in New Hampshire's north country,” Final Report 95.

Puettmann, M. E., and Wilson, J. B. (2005). "Life-cycle analysis of wood products: cradle-to-gate of residential wood building materials," Wood and Fiber Science. 27(CORRIM Special Issue), 18-29.

Putsche, V. (2004). "Pyrolysis process design, costs and modeling. Thermochemical platform analysis,” NREL National Renewable Energy Laboratory, 75 pp.

Renewable Oil International, LLC. (2009). “Techno-economic analysis: Preliminary assessment of pyrolysis oil production costs and material energy balance associated with an ROI 100-dtpd fast pyrolysis system,” Unpublished Report. 12 pp.

Ringer, M., Putsche, V., and Scahill, J. (2006). "Large-scale pyrolysis oil production: A technology assessment and economic analysis,” NREL National Renewable energy Laboratory. NREL/TP-510-37779.

Article submitted: Sept. 2, 2010; Peer review completed: Oct. 2, 2010; Revised version received and accepted: Oct. 29, 2010; Published: November 2, 2010. 